\title{
Effectiveness of Pranayama on reducing the anxiety among the alcoholic patient in BharathMatha De-addiction center
}

\author{
${ }^{*}$ Mrs. GeraldRoseline $M{ }^{* *}$ Mrs.Prabavathy $S \&{ }^{* * *}$ Mr.Dhivagar S
}

\begin{abstract}
:
Alcohol is a drug that is dependent upon by the majority of our society. Several people across the world become addicted to alcohol Objectives- To find out the effectiveness of Pranayama on reducing the anxiety among the alcoholic patients. Method: Quasi Experimental Research design was adopted for the study. A sample of 40 male alcoholic patients was selected by using simple Random Sampling Technique. The Intervention of Pranayama was given for a duration of 1hour daily for 21 days. Result: The Mean score value of pre-test was 14.80, post test was 4.23 and obtained ' $t$ ' value 18.759 was highly significant (0.000) at $p<0.001$ level. Asignificant association between the level of anxiety and history of chronic illness was seen atp<0.05 level.Conclusion: The effectiveness of pranayama highly reduces the anxiety level among alcoholic patients.
\end{abstract}

Keywords: Pranayama, Anxiety, Alcoholics.

\section{INTRODUCTION}

Alcohol is a drug that is dependant upon by the majority of our society. Several people across the world become addicted to alcohol; alcohol consumption is the world's third largest risk factor for disease and disability ${ }^{1}$.Alcoholism refers to the use of alcoholic beverages to the point of causing damage to the individual, Society or both. Alcohol withdrawal syndrome is the set of symptoms seen when an individual reduces or stops alcohol consumption after prolonged periods of excessive alcohol intake. 4

Alcohol Detoxification or detox for alcoholics is an abrupt stop of alcohol drinking coupled with the substitution of drugs, such as benzodiazepines.
Individual at the risk of severe withdrawal syndrome, significant or acute comorbid conditions are generally treated as inpatients. $^{3}$

Some symptoms like depressed mood and anxiety may take weeks or months to abate while other symptoms persist longer due to persisting neuro-adaptations. Only $10 \%$ of patients fully recover during detoxification, and attend Alcohol anonymous group meetings. Among the $10 \%, 80 \%$ of them relapse due to ethanol withdrawal anxiety(Janet Firshein, 2009). (2)

So they need some complementary management to overcome those problems. PRANAYAMA is a type of yogic breathing a unique method for balancing the autonomic nervous system and influencing psychological and stress-related disorders. 
Pranayama breathing has Inhalation (puraka), Retention (kumbhaka) and Exhalation (rechaka) components. Gush of rich oxygenated air enables the normal regulation of GABA receptors and decreases cortisol level.(5)

\section{STATEMENT OF THE PROBLEM:}

The Effectiveness of Pranayama On Reducing The Anxiety Among The Alcoholic Patients In BharathMatha DeAddiction Center At Puducherry.

\section{OBJECTIVES:}

- To assess the level of anxiety among the alcoholic patients.

- To evaluate the effectiveness of pranayama on reducing the level of anxiety among the alcoholic patients.

- To associate the level of anxiety among the alcoholic patients with the selected demographic variables

\section{HYPOTHESES:}

- $\quad \mathbf{H}_{\mathbf{1}}$ : There is a significant difference in the reduction of anxiety among alcoholic patients who have received pranayama.
- $\mathbf{H}_{2}$ : There is a significant association between the level of anxiety among the alcoholic patients and the selected demographic variables.

\section{RESEARCH METHODOLOGY:}

Quasi experimental research design was adopted for the study. The study was conducted in the alcoholic patients residing amongBharathMatha deaddiction center at Puducherry. A total of 40 alcoholic patients were selected by using Simple Random Sampling Technique and Pre-test data were collected by Interview method by using Modified Hamilton Anxiety

Rating Scale and Pranayama was given for them everyday morning from 6.30am for 21 days. Followed by the Post test was conducted by using same tool.

\section{RESULT:}

The data were analyzed by using descriptive and inferential statistics. The findings of the study were described based on the objectives.

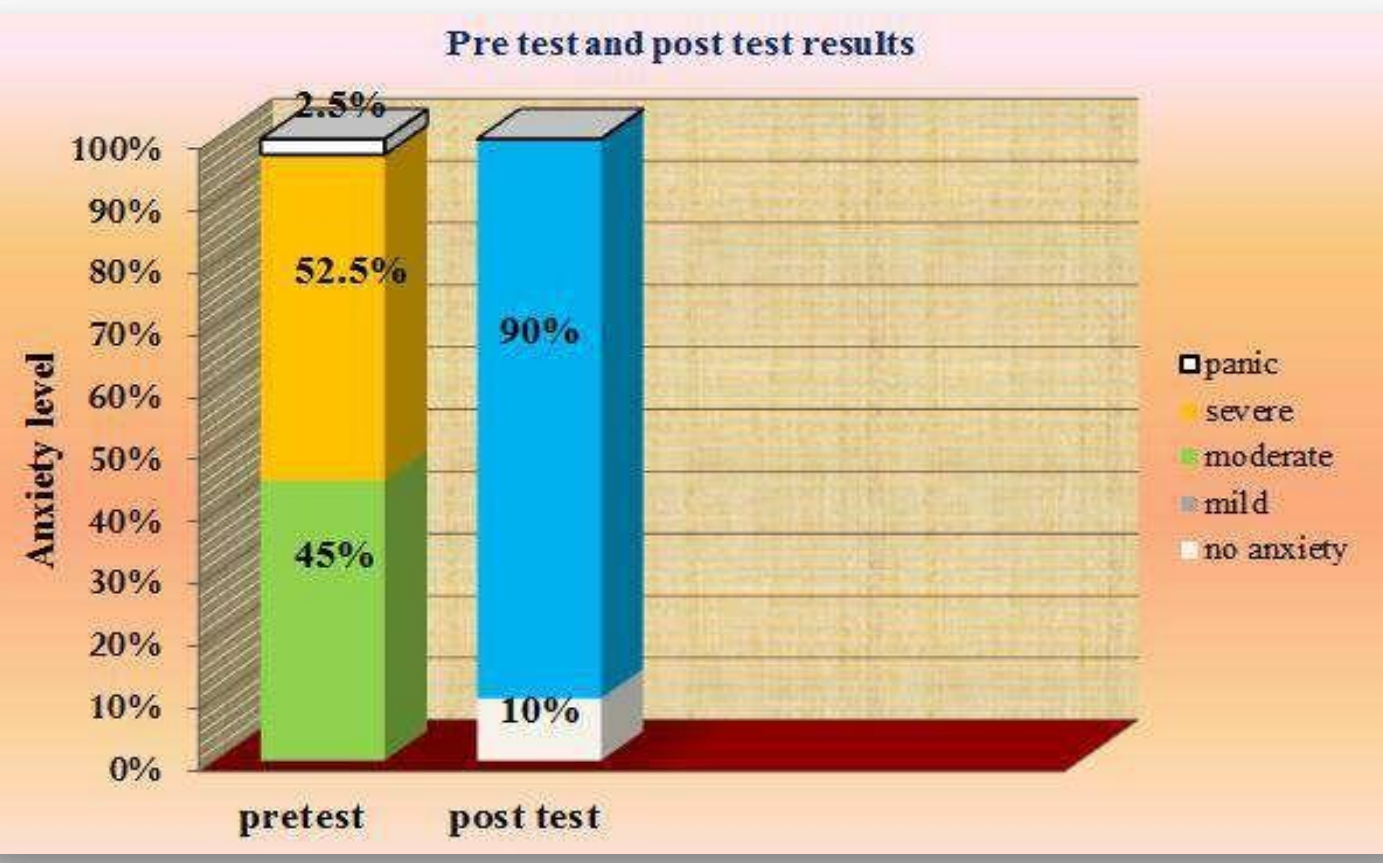


Figure 1 shows Pre-test level of anxiety 52.5\% having severe level of anxiety, 45\% of them were moderate and $2.5 \%$ of them were panic. After Pranayama, $90 \%$ of the patients had mild level of anxiety and $10 \%$ of them had no anxiety.

\begin{tabular}{|c|c|c|c|c|c|c|c|c|c|}
\hline \multirow{2}{*}{ SI no } & \multirow{2}{*}{ Variables } & \multicolumn{2}{|c|}{ Pretest } & \multicolumn{2}{|c|}{ Post Test } & \multicolumn{2}{|c|}{ Improvement } & \multirow{2}{*}{$\begin{array}{c}\text { "t" } \\
\text { Value } \\
\text { (df) }\end{array}$} & \multirow{2}{*}{$\begin{array}{c}P \\
\text { Value }\end{array}$} \\
\hline & & Mean & $\begin{array}{l}\text { Standard } \\
\text { Deviation }\end{array}$ & Mean & $\begin{array}{l}\text { Standard } \\
\text { Deviation }\end{array}$ & Mean & $\begin{array}{l}\text { Standard } \\
\text { Deviation }\end{array}$ & & \\
\hline 1 & Anxiety & 2.575 & 0.54948 & 1.9 & 0.3038 & 10.575 & 3.565 & $\begin{array}{c}18.759 \\
(39)\end{array}$ & $\begin{array}{c}0.000 \\
* * *\end{array}$ \\
\hline
\end{tabular}

\section{H1: There is a significant difference in the reduction of anxiety among the alcoholic patients who have received pranavama}

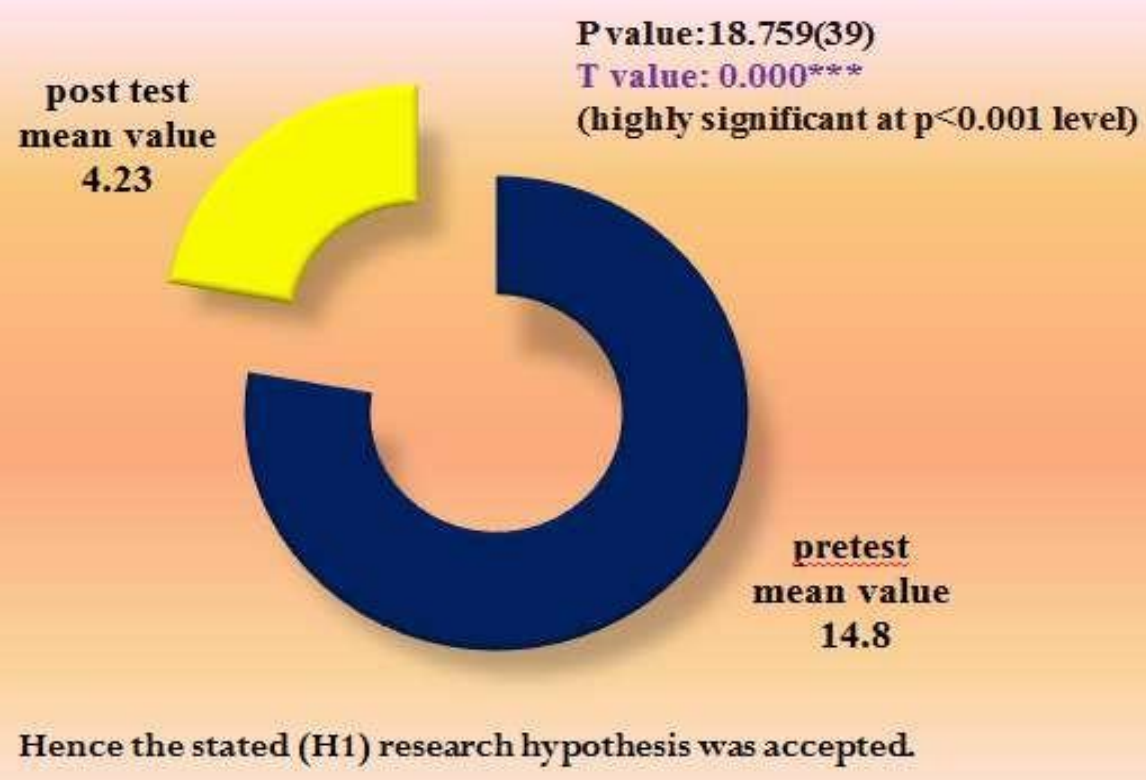

Table 2, Figure 2 shows that the Post test mean level of anxiety score 4.23 was lower than the pretest score 14.80 and the standard deviation level in the post test was 2.896 and in pretest was 5.039 . The Obtained " $\mathrm{t}$ " value 18.759 was highly significant $(0.000)$ at $\mathrm{p}<0.001$ level. Hence the Research Hypothesis $\mathrm{H}_{1}$ was accepted

Table 3 shows that chi square value is 13.155 . The " $p$ " value is 0.041 , which is lesser than the table value at $\mathrm{p}<0.05$ level of significance. Therefore there is a significant relationship between the level of anxiety and their chronic illness. Hence the Research Hypothesis $\mathbf{H}_{2}$ was accepted 
H2: There is a significant association between the level of anxiety among the alcoholic patients and the selected demographic variables.

- Frequency, Percentage, Distribution and Chi-Square Value of Level of Anxiety among the Patients with their history of chronic illness. $\mathrm{N}=40$

\begin{tabular}{|c|c|c|c|c|c|c|c|}
\hline \multirow[b]{2}{*}{$\begin{array}{c}\text { History of } \\
\text { chronic illness }\end{array}$} & \multicolumn{3}{|c|}{ Anxiety level } & \multirow[b]{2}{*}{$\begin{array}{c}\text { Frequency } \\
\text { (n) }\end{array}$} & \multirow[b]{2}{*}{$\begin{array}{c}\text { Percentage } \\
(\%)\end{array}$} & \multirow{2}{*}{$\begin{array}{l}\text { Chi } \\
\text { square } \\
x^{2}\end{array}$} & \multirow[b]{2}{*}{$\begin{array}{c}\text { 'p' } \\
\text { value }\end{array}$} \\
\hline & Moderate & Severe & Panic & & & & \\
\hline Diabetes & 2 & 0 & 0 & 2 & 5 & \multirow{4}{*}{13.155} & \multirow{4}{*}{$\begin{array}{c}0.041 \\
*\end{array}$} \\
\hline Hypertension & 2 & 4 & 0 & 6 & 15 & & \\
\hline Both & 0 & 4 & 1 & 5 & 12.5 & & \\
\hline None & 14 & 13 & 0 & 27 & 67.5 & & \\
\hline
\end{tabular}

$* \mathrm{p}<0.05$ level of significance

\section{CONCLUSION:}

The Present study revealed that pranayama is effective in reducing the level of anxiety among the alcoholic patients. So regular classes on pranayama can be conducted to the patients in the de-addiction centre and to be their family members to enhance the positive vibration and free from psychological issues.

\section{REFERENCES:}

1. Anderson P (1996) Alcohol and risk of physical harm, In Holder HG, Edwards evidence and issues. Oxford, England, Oxford University Press P-82-113

2. Fergusson DM, Text book of Alcohol Consumption and associated problems,, Volume 4, Oxford Medical Publications

3. Sreevani, text of Psychiatric Nursing, Jay pee Health Sciences Publications, fourth edition.

4. Amitkauts and Neelam Sharma (2000), Text book of Yoga, $4^{\text {th }}$ edition, Elsevier Publication, Pg-45,36,52

5. Iyengar, B.K.Sundar raja (1995), "The Light On Pranayama: the Yogic Art of Breathing" $5^{\text {th }}$ edition, Mukthi Publications, Pg.20-35 